\title{
PSYCHE
}

\begin{tabular}{lll}
\hline Vol. 85 June-September, 1978 & No. 2-3 \\
\hline
\end{tabular}

\section{GEOGRAPHICAL DISTRIBUTION AND BIOLOGICAL OBSERVATIONS OF CYPHODERRIS (ORTHOPTERA: HAGLIDAE) WITH A DESCRIPTION OF A NEW SPECIES}

\author{
By GlenN K. Morris ${ }^{1}$ AND DARryl T. GWyNNE ${ }^{2}$
}

\section{INTRODUCTION}

With the exception of Prophalangopsis obscura (F. Walker) from India, Cyphoderris are sole survivors of a primitive orthopteran family, the Haglidae, abundant in the Triassic and ancestral to modern Ensifera (Zeuner, 1939; Ander, 1939; Ragge, 1955; Sharov, 1968).

There are presently two recognized species of Cyphoderris: $C$. monstrosa Uhler and $C$. buckelli Hebard. Their most dramatic distinguishing feature is the presence in C. monstrosa, and the absence in $C$. buckelli, of a prominent ventrally-directed sternal process, shaped like the claw of a hammer and located on the IXth sternum (Hebard, 1934). Specimens of both species have been extensively collected from mountainous areas of the North American northwest.

When Uhler established Cyphoderris in 1864 he had before him two adult male specimens. He published body measurements for both of these and there is a substantial size difference e.g. body length $22 \mathrm{~mm}$ for one specimen and only $16 \mathrm{~mm}$ for the other. These specimens are in the Museum of Comparative Zoology, Harvard University and we have examined them. The larger has a prominent

\footnotetext{
'Erindale College and Department of Zoology, University of Toronto, Mississauga, Ontario, L5L 1C6, Canada.

2Department of Zoology and Entomology, Colorado State University, Fort Collins, Colorado, 80523, U.S.A.

Manuscript received by the editor November 15, 1978.
} 
sternal process and is $C$. monstrosa of present usage; the smaller specimen lacks the process and is $C$. buckelli of Hebard. It is the $C$. buckelli specimen which bears a red 'Type 792' label. Uhler's description concentrates on the larger specimen. Thus monstrosa is said to have a "pointed keel-like elevation, projected backwards upon the segment, grooved and emarginated at tip", i.e. a sternal process. He does not indicate that such a structure is absent from the other specimen.

Caudell (1904) described a variety of C. monstrosa which he called Cyphoderris monstrosa piperi. His types, which we have seen, are a male and a female from Mt. Rainier, Washington, housed in the U.S. National Museum. The male has a sternal process identical with that of Uhler's larger specimen and the female has Ander's organs (see below).

In 1922 Fulton collected a series of males in Oregon about $30 \mathrm{mi}$. southwest of Crater Lake (Fulton, 1930). He compared these with specimens furnished him by E. R. Buckell from southern British Columbia and found that Buckell's specimens lacked a genitalic process. Drawings were sent to Nathan Banks and to Caudell who compared them with the types of monstrosa and piperi.

It might now have become apparent that Uhler's types differed in their genitalia and that only the larger was of the same species as piperi. Since the published description applied substantially to the larger specimen one would then have expected it to be designated as monstrosa. But for some reason piperi was given specific status by Fulton and applied to the taxon with the sternal process while Uhler's name was conferred upon the smaller of Uhler's two species. Probably it was at this point that the red type label was appended at Harvard.

Hebard (1934), responding to Uhler's published description, recognized piperi as a synonym of monstrosa and gave the name buckelli to the species without the sternal process. It is clear that he did not examine Uhler's types and was unaware that one of these was his new species. Uhler did not designate a holotype and so in accordance with Article 74 of the code and in the interest of taxonomic stability, we here designate as lectotype the larger of the two specimens in his type series, that possessing the sternal process. This ensures that application of the name monstrosa continues in conformity with present custom. 
A third species of Cyphoderris, C. strepitans, is described here. Its distribution lies southeast of both monstrosa and buckelli (Figure 5), populations of strepitans being originally considered as southern range extensions of monstrosa (Alexander, 1935; Willey and Willey, 1963). C. strepitans appears to be most similar in morphology and calling song to buckelli but is readily distinguished from the latter species by the structure of the male terminalia.

We have made use of the following abbreviations: ROM/ Royal Ontario Museum, Toronto, Canada; UMMZ/ University of Michigan, Museum of Zoology, Ann Arbor; ANSP/ Academy of Natural Sciences, Philadelphia; CNC/ Canadian National Collection, Ottawa, Canada; MCZ/ Museum of Comparative Zoology, Harvard University; USNM/ National Museum of Natural History, Smithsonian, Washington, D.C.

\section{Cyphoderris strepitans new species}

Figures 1 and 2

The specific name refers to the calling song: strepitans (Latin) 'making a great noise'.

\section{SYNONOMY:}

Cyphoderris monstrosus, Thomas (not Uhler), 1876. Proc. Davenp. Acad. Nat. Sci. I, p. 263. Wind River, Wyo.

Cyphoderris monstrosa, Hebard (in part not Uhler), 1934. Trans. Am. ent. Soc. 59, p. 374. Pearl, Col.

Cyphoderris monstrosa, G. Alexander (not Uhler) 1935. Ent. News 46, p. 30. Park Range (Pearl) Col.; ibid 1941. Univ. Col. Studies 1, p. 136.

Cyphoderris monstrosa, Willey \& Willey (not Uhler) 1963. Ent. News 74, p. 200. Los Pinos Pass, Col.

Cyphoderris monstrosa, Evans (not Uhler) 1970. Bull. Mus. Comp. Zool. Harv. 140, p. 484. Jackson Hole, Wyo.

Holotype. Adult o. Park Range 24.7 mi. west of Cowdrey via Pearl, nr Big Creek Lakes, Jackson Co., Col., U.S.A.; 19 June 1976; Coll. G. K. Morris \& D. T. Gwynne (Deposited ROM).

DESCRIPTION OF MALE TYPE. Body length (fastigium to paraprocts in dorsal view) $18.6 \mathrm{~mm}$; pronotum mid-line length $7.2 \mathrm{~mm}$; caudal pronotum width $7.8 \mathrm{~mm}$; maximum exposed tegminal length in dorsal view $8.2 \mathrm{~mm}$; length in lateral view of left metathoracic fermur $8.3 \mathrm{~mm}$. 


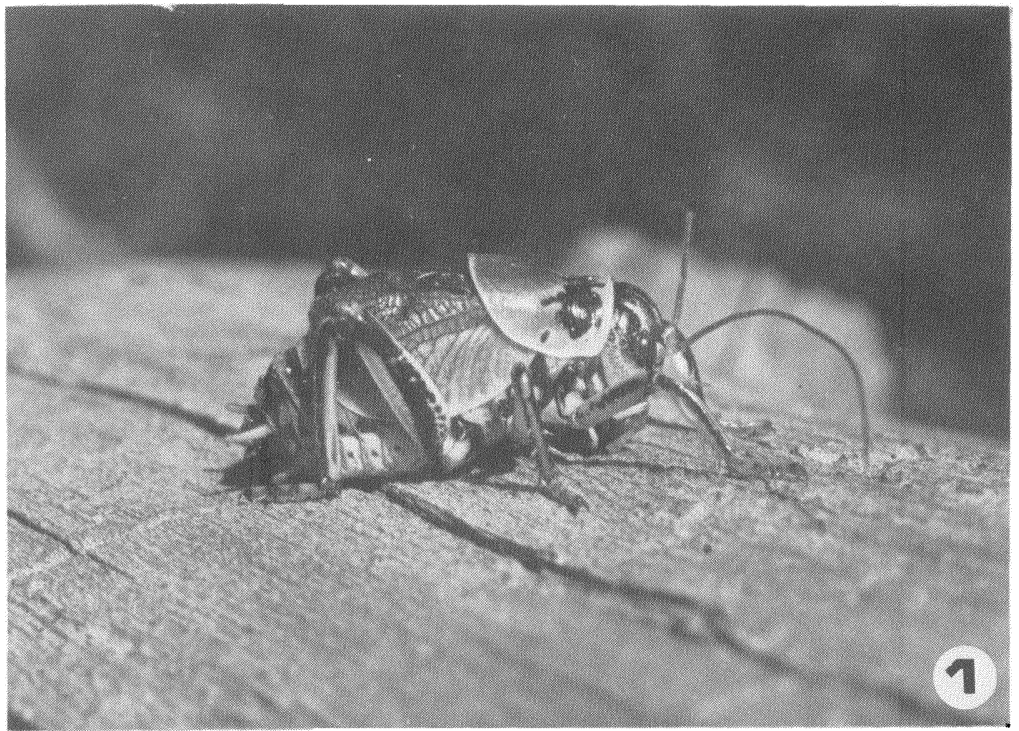

Figure 1. Adult male C. strepitans.

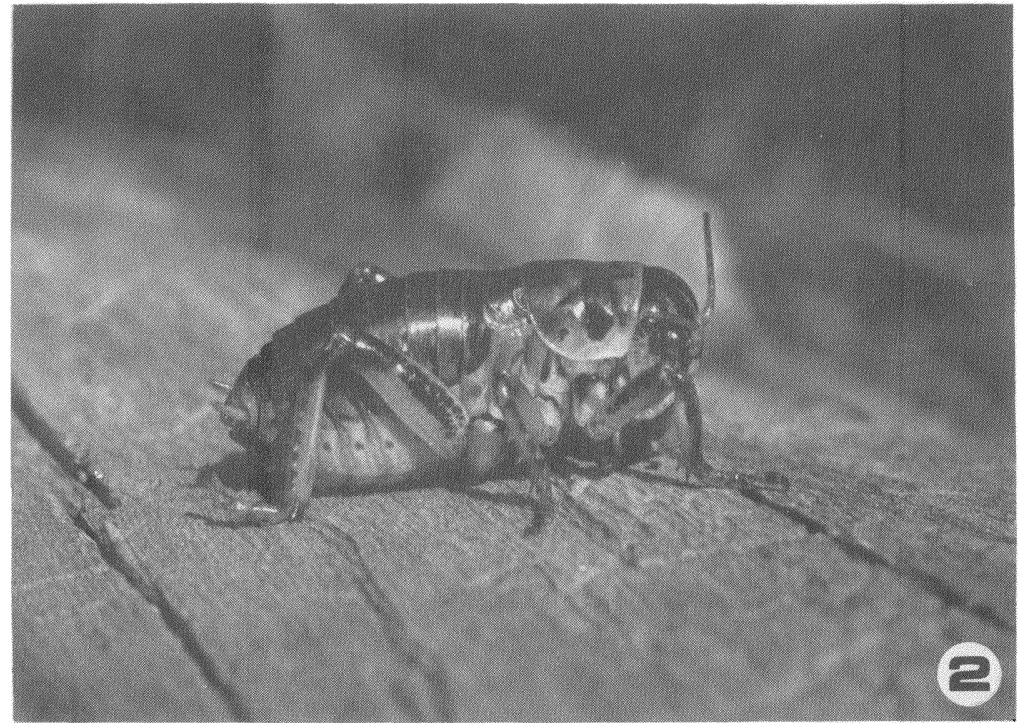

Figure 2. Adult female C. strepitans (both antennae broken). 
Allotype. Adult o. Los Pinos Pass, Saguache Co., Col., U.S.A.; 17 June 1977; Coll. D. T. Gwynne (Deposited ROM).

DESCRIPTION OF FEMALE ALLOTYPE. Body length (fastigium to extremity of epiproct in dorsal view) $21.5 \mathrm{~mm}$; pronotum mid-line length $5.9 \mathrm{~mm}$; caudal pronotum width $5.4 \mathrm{~mm}$; length of ovipositor $2.0 \mathrm{~mm}$; length in lateral view of left metathoracic femur $9.6 \mathrm{~mm}$.

DiAgNosis. Adult males of strepitans are similar in size and coloration to buckelli, but readily distinguished by the presence of the sternal process (Figures $3 \& 4$ ). Males of both strepitans and buckelli are generally smaller than males of monstrosa. In life they usually lack the vivid pink coloration of monstrosa's venter, their venters being instead crearn white. The styli of the IXth sternum are strongly depressed in monstrosa; viewed from above each stylus is sublanceolate and broadest at its base; they are inserted on the lamellate dorsal projection of the IXth sternum at a distance slightly greater than the stylus length. By contrast the styli of strepitans are distally dilated and broadly rounded (mitten-like), gently arcuate and tapering slightly to the base; they are inserted close together immediately adjacent to the mid-line with less than one stylus length between their bases.

The sternal process of monstrosa, viewed in lateral outline, follows a broadly concave arc beyond the base of the styli to where it turns abruptly downward; in strepitans this arc is shorter and much shallower. From the end of the arc the process of monstrosa is more strongly reflexed than in strepitans and is often bent sharply forward at its extremity.

We are unable at present to distinguish between fernales of buckelli and strepitans but both of these species may be separated from monstrosa by their lack of the 'stridulatory' organs of Ander (1938). In C. monstrosa these structures are located dorsolaterally at the junction of abdomen and thorax (Ander, 1938; Kevan, 1954; Dumortier, 1963). Each organ consists of a row of robust posteriorly-directed recurved teeth on the slightly swollen posterolateral edge of the metanotum. The teeth contact a patch of transverse ridges on the first abdominal tergite during telescoping of the abdominal segment. Ander's organs are present in both sexes and are readily seen in later stadia of immatures. While buckelli sometimes possesses weak thoracic teeth, it never exhibits the ridged 


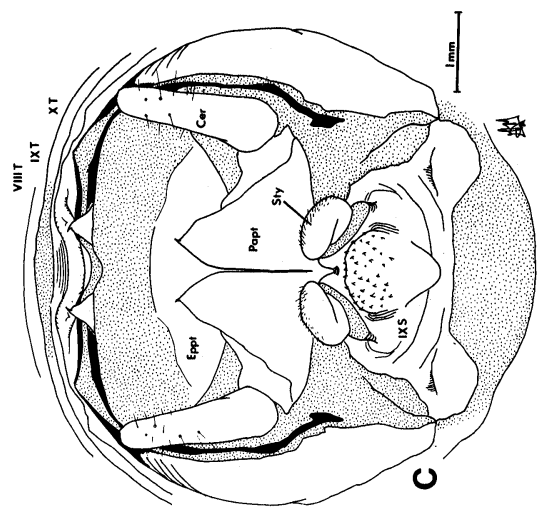

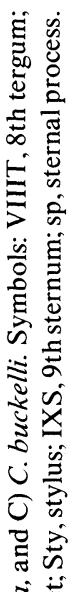
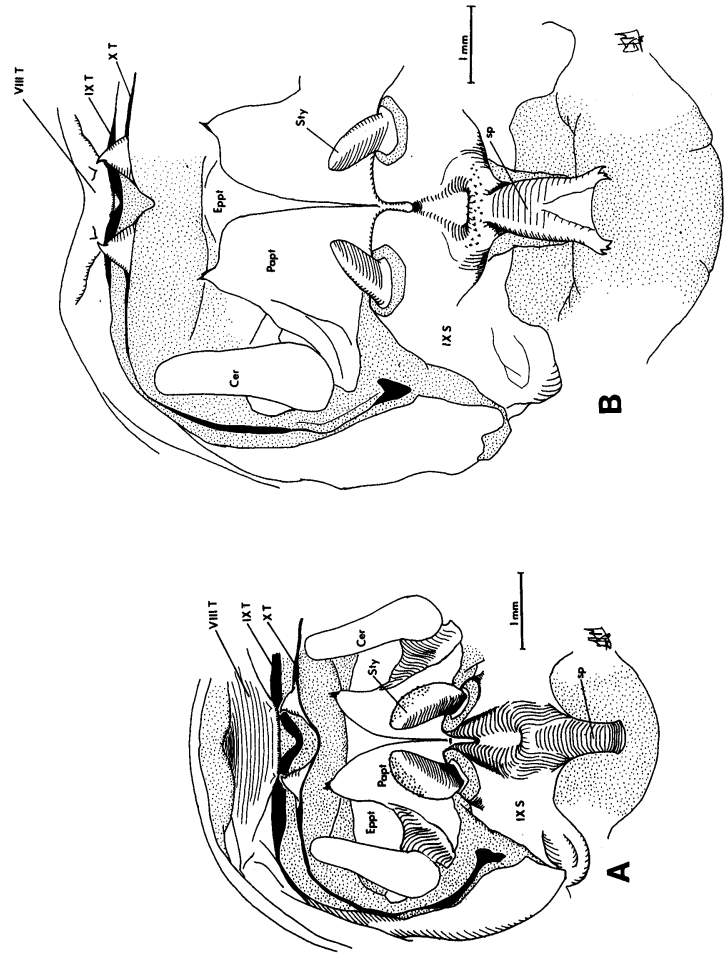

过

ई ส

ن 施

ลิ น

जे

흘

论 总

४

. ํㅝㅇ

它

岁

这

.

흐응

㦴

ल

壱

政 


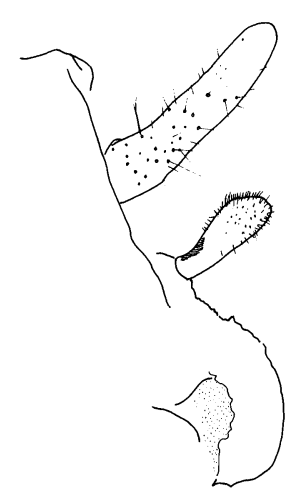

A

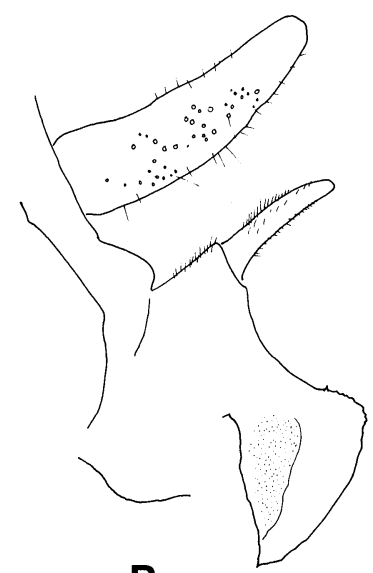

B

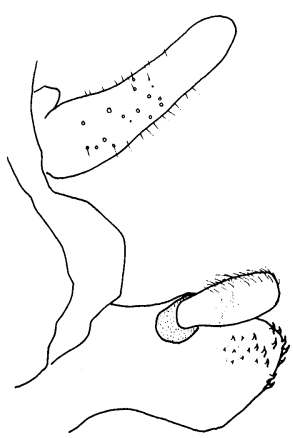

C

Figure 4. Lateral view of IXth sternum, A) C. strepitans, B) C. monstrosa, and C) C. buckelli.

patch. No stridulatory function has been established for these structures.

Paratypes. 9 adult $\hat{\partial} \hat{\partial}$, same data as holotype (ROM, MCZ, \& UMMZ); 1 adult + , same data as holotype (ROM); 4 adult $\hat{\delta} \hat{\sigma}$, Cowdrey, $8.8 \mathrm{mi}$. west on road to Pearl, 4 June 1978 (G. K. Morris \& D. T. Gwynne) (ROM \& Colorado State Univ., Ft. Collins); 1 adult $\widehat{\delta}$, Park Range nr Pearl, Col., 17 Aug. 1932 (G. Alexander) (ANSP); 1 adult $\hat{\delta}$, Pearl, Col., 17 Aug. 1932 (G. Alexander)

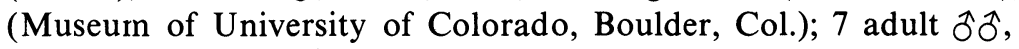
Los Pinos Pass, Col., 17 June 1977 (D. T. Gwynne) (USNM \& CNC); 1 imm. ô, Los Pinos Pass, Col., 17 June 1977 (D. T. Gwynne) (ROM); 1 adult $\hat{\alpha}$, Dunraven Pass, Yellowstone Nat. Pk, Wyo., 25 June 1930 (E. C. Van Dyke) (UMMZ); 1 adult 우, Jackson Hole Res. Stn, Grand Teton Nat. Pk, Wyo., Aug. 1967 (H. E. \& M. A. Evans) (USNM); 1 imm. $0^{\star}$, Jackson Hole Res. Stn, Grand Teton Nat. Pk, Wyo. (H. E. \& M. A. Evans) (USNM); 1 adult , Stratton Exp. Watershed, nr Saratoga, Wyo. (J. M. Schmid) (USNM). 


\section{Key to Cyphoderris Species \\ (Males only)}

1. Subgenital plate (IXth sternum) with prominent ventrallydirected process (Figures $4 \mathrm{a}, \mathrm{b}) \ldots \ldots \ldots \ldots \ldots \ldots \ldots \ldots \ldots \ldots \ldots$ Sternal process absent (Figure 4c) ..... C. buckelli Hebard

2. IXth sternum strongly produced posteriorly; sternal process with an angularly forward-bent tip, often appearing terminally cleft and toothed; styli of IXth sternum depressed, sublanceolate (Figure 3b); Ander's organ ridge-patch present and thoracic teeth robust; fastigium often weakly rugose $. . . \ldots \ldots \ldots . .$. .......................... monstrosa Uhler

Posterior of sternal process not angular but rounded, never terminally cleft and toothed (Figure 3a); Ander's organ absent or if present, only as weak thoracic teeth; styli of IXth sternum mitten-like; fastigium smooth ... C. strepitans new species

\section{GeOgRaPhical Distribution}

C. strepitans, as presently known, is confined to the mountains of Colorado and Wyoming (Figure 5). Its distribution is disjunct from that of buckelli and monstrosa. The broad valley of the Snake River isolates it on the northwest from the most southerly populations of Idaho monstrosa; if overlap occurs it must be north of Yellowstone in southern Montana.

C. monstrosa is found from the Canadian Rockies in the southwest corner of Alberta, west through southern British Columbia. It reaches much farther north than buckelli, to Quesnel and to Smithers B.C. (This latter record exceeds the northern extent of our map and could not be plotted; Smithers is about 700 miles north of the Canada/U.S. border.) A western arm of monstrosa extends down the Cascades, reaching almost to northern California. A less documented eastern arm crosses western Montana to a cluster of localities in the Salmon River Mts of central Idaho.

C. buckelli has a more restricted range. It lies between these arms, overlapping broadly with monstrosa in southern B.C. and extending south through northern Idaho. There are interesting isolated records from Columbia Falls, Montana and from near Seneca in east central Oregon. Though their distributions overlap substantially we have not found monstrosa and buckelli together at the demic level. 


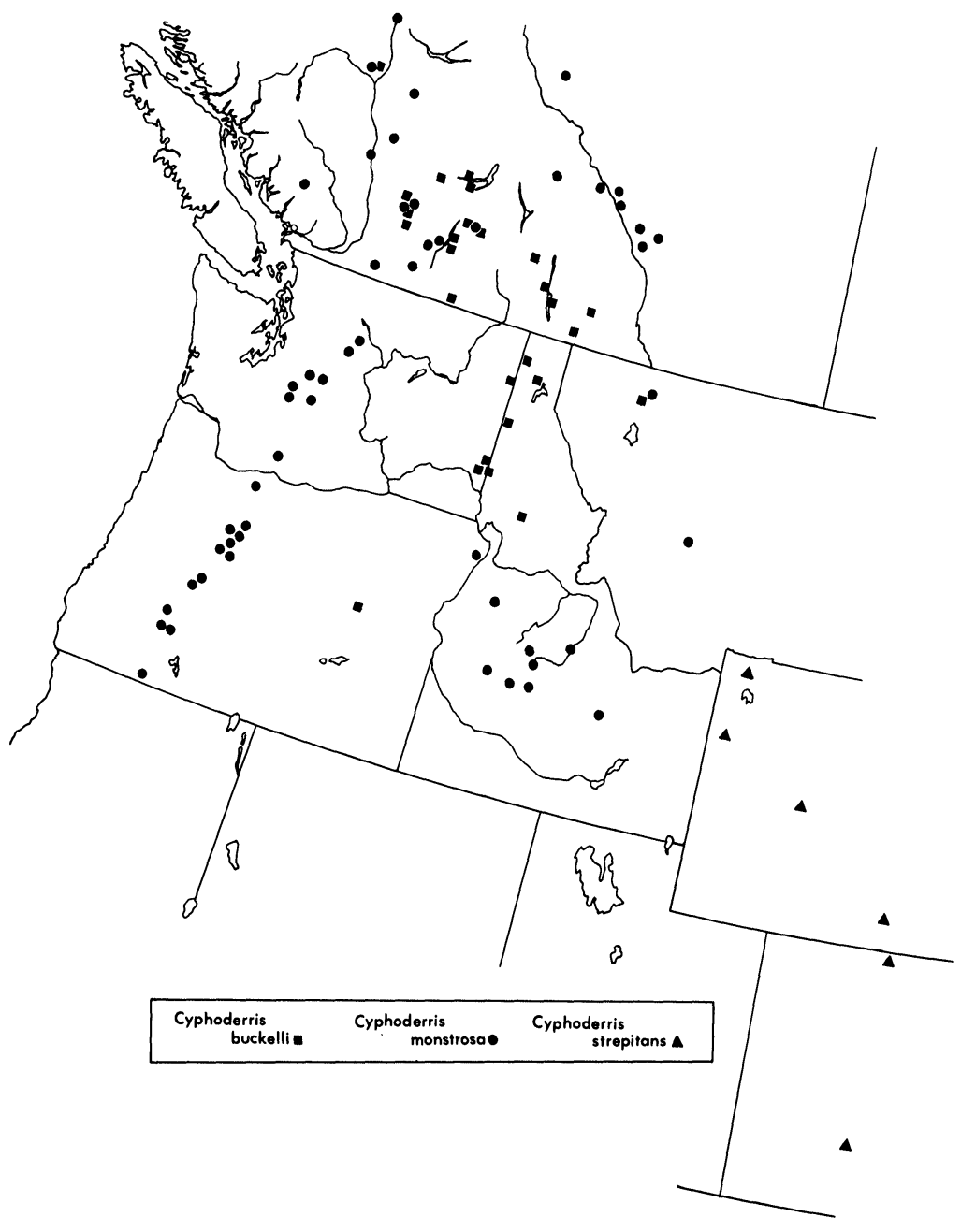

Figure 5. Geographical distribution of Cyphoderris. 
However Buckell (1924) states that both species have been seen at Nicola, B.C. "in large numbers during late May feeding together upon flowers of Amelanchier....".

We have examined about 300 specimens of monstrosa and 200 of buckelli. In addition to the type, allotype and paratypes of strepitans, we have seen 20 or so alcoholic specimens supplied by Dr. R. Willey of the Univ. of Chicago. Dr. Willey's material is from Los Pinos Pass, Col., a locality which he discovered in 1962 (Willey \& Willey, 1963).

All plotted localities are based upon actual examination of specimens excepting Wind River, Wyo. This record is taken from Thomas (1876) on the strength of his illustration of an adult male. Though the drawing is small the shape of the sternal process is apparent and marks the specimen as strepitans. A listing of localities is given below for each species.

C. strepitans: WyOMING: Dunraven Pass, Yellowstone N. Pk; Jackson Hole, Grand Teton N. Pk.; Wind River, Fremont Co.; Stratton Exp. Watershed, nr Saratoga, Carbon Co. COLORADO: Park Range, nr Big Creek Lks, Jackson Co.; Cowdrey, 8.8 mi. west, Jackson Co.; Los Pinos Pass, Saguache Co.

C. monstrosa: BRITISH COLUMBIA: Smithers; Quesnel; Chilcotin nr Williarns Lk; Lac La Hache; Clinton; Lillooet; Whistler Mt., Garibaldi Prov. Pk; Salmon Arm; Field, Yoho N. Pk; Glacier N. Pk; Monck Prov. Pk; Merritt; Lumby; Peachland; Fish Lk, nr Summerland; Manning Prov. Pk; Hedley. ALBERTA: Jasper N. Pk; Mt. Eisenhower Cpgrd, Banff N. Pk; Sulphur Mt., Banff N. Pk; Bragg Creek, w. of Calgary; Barrier Lk, Kananaskis Valley; Kananaskis Lks, Kananaskis Valley. MONTANA: Belton, Flathead Co.; 2 mi. s. Elliston, Powell Co. IDAHO: McCall, Valley Co.; Challis, Custer Co.; Beach Cr., nr Bull Trout Lk, Custer Co.; Red Fish Lk, Custer Co.; Centerville, Boise Co.; 22 mi. ne. Idaho City, n. fork Boise R., Boise Co.; Camas Co.; Arco, Butte Co. WAShington: Lk. Wenatchee St. Pk, Chelan Co.; Entiat R. Trail, Chelan Co.; 2 mi. se. Easton, Kittitas Co.; Stampede, King Co.; Paradise Valley, Mt. Rainier N. Pk.; Berkeley Park, Mt. Rainier N. Pk; Gooseprairie, Yakima Co.; Trout Lk Cpgrd, Klickitat Co. OREGON: Mt. Hood, Hood R. Co.; Hat Point, Wallowa Co.; Middle Sister, Lane Co. \& Deschutes Co.; McKenzie Pass, Lane Co. \& Deschutes Co.; Salt Creek Falls, Lane Co.; Waldo Lk, Lane Co.; Lost Lk, Willamette Nat. For., Linn Co.; North Santiam R., Linn Co.; Pinehurst, 
Jackson Co.; Union Creek, Jackson Co.; Crater Lk N. Pk, Klarnath Co.; Douglas Co.; Olallie Lk, Marion Co.; Mt. Jefferson, Jefferson Co.

C. buckelli: BRITISH COLUMBIA: Chilcotin; Paul Lk Prov. Pk; Squilax; Salmon Arm; Nicola Lk; 2 mi. s. Merritt; Aspen Grove; Vernon; Lumby; Kelowna, nr airport; 3 mi. se. Rutland; Okanagan Falls; Rock Creek; Yahk; Ainsworth; Rosebery Prov. Pk; Cranbrook; Boswell, Kootenay Lk. IDAHo: Reeder Bay, Priest Lk, Bonner Co.; Sandpoint, Bonner Co.; 10 mi. s. Coeur d'Alene, Kootenai Co.; Moscow Mt., Latah Co.; Moscow, Latah Co.; Kamiah, Lewis Co. WAshington: Newport, Pend Oreille Co.; Palouse, Whitman Co.; Pullman, Whitman Co. MONTANA: Columbia Falls, Flathead Co. OREGon: 3 mi. e. Seneca, Grant Co.

\section{HABITAT AND FEEDING BEHAVIOR}

The distribution of Cyphoderris corresponds roughly with the Cordilleran forest province (Gleason \& Cronquist, 1964). In southern British Columbia $C$. buckelli occurs in the Dry Forest biotic area (Cowan \& Guiguet, 1965) characterized by yellow pine (Pinus ponderosa) and at higher elevations, by interior Douglas fir (Pseudotsuga menziesii). Amelanchier (serviceberry), Balsamorhiza (arrow-leaf balsam-root) and Berberis (tall Oregon grape) are common understory plants in this association. In spring the nymphs and adult fernales of $C$. buckelli feed upon the flowers of these plants; night collecting at blooms is a good way to obtain specimens.

C. buckelli is also found in the Columbia Forest biotic area, the so-called interior wet belt of British Columbia. In 1977 we located large populations adjacent to Kootenay Lake near Boswell and at Rosebery on Slocan Lake.

C. monstrosa does occur in Dry Forest e.g. at Monck Prov. Park in southern British Columbia, but it is typically encountered in Subalpine Forest. Lodgepole pine (Pinus contorta) and Englemann spruce (Picea engelmannii) are characteristic of the Sub-alpine biotic area. In the Kananaskis Valley of southern Alberta we observed nymphs and adults to feed upon staminate cones of lodgepole pine (this before the cones reach a 'loose pollen' stage). Consumption was established by identifying cone bracts in the feces of field-caught specimens. Also caged insects were given cones and in most cases overnight they ate large portions. 
It is presumably to feed upon staminate cones that $C$. monstrosa nymphs and adult females are observed at dusk climbing high into the trees. A useful method of collection is to search tree trunks with a flashlight just after sunset. The insects are always discovered oriented head upward. More often than not they occur in groups of 2 to 4 on the same trunk, which suggests that they may aggregate during their daytime stay in the leaf litter of the forest floor.

David Lightfoot of Oregon State University has studied $C$. monstrosa at Three Sisters in the central Oregon Cascades. He found this species abundant there in drier, more open stands of lodgepole pine and mountain hemlock (Tsuga mertensiana) above $5000^{\prime}$ elevation. In contrast to our observations of ascent as the evening progresses Lightfoot notes that the singers begin high in the trees (about $6 \mathrm{~m}$ ) and gradually occupy lower and lower perches until singing at ground level.

C. strepitans is found in both subalpine forest and high altitude sagebrush prarie. The holotypic site near Big Creek Lakes is an open forest of subalpine fir (Abies concolor) and lodgepole pine at an altitude of $8800^{\prime}$. At Los Pinos Pass, Colorado, strepitans is found in aspen woods adjacent to open areas of prairie. The mature aspen (Populus tremuloides) has an understory of subalpine fir and englemann spruce (altitude 10,200'). Two predominant ground cover plants at both sites are kinnikinik (Arctostaphylos spp.) and a shrubby juniper (Juniperus communis). In the high altitude $\left(8400^{\prime}\right)$ sagebrush (Artemesia tridentata) prairie of North Park, Colorado, the density of singing males appeared to be much greater than in the nearby pine forest of the holotypic site to the east. C. strepitans is also very numerous in the sagebrush areas (altitude $6700^{\prime}$ ) of Grand Teton National Park, Wyoming. In late June, 1978, aggregations of singing males were easily heard while we drove along park roads at night. Thus, $C$. strepitans may be considered a predominantly sagebrush species although occurring in open forest habitats in the vicinity of sagebrush prairie.

\section{Acoustic BeHAVIOR}

Males of all three species produce a succession of short musical trills, beginning in late evening and continuing well past midnight if weather permits. C. buckelli invariably sing near the ground from low shrubs (knee-height), the bases of tree trunks or on the forest 
floor itself. The same is true of C. strepitans. Only C. monstrosa climb high into the trees as the night's signalling progresses. At Monck Park singing heights in excess of $5 \mathrm{~m}$ were common and an hour after sunset collection without climbing trees becomes impossible.

The calling songs are generated by tegminal stridulation. As in Gryllidae the tegmina are morphological mirror-images, both left and right bearing a functional file and scraper. Unlike gryllids however, which maintain a characteristic 'right above' forewing overlap, the overlap of a Cyphoderris male may change during his lifetime and both files take part in his stridulation.

Certain Tettigoniidae also have mirror-image tegmina and two functional files: Megatympanon speculatum Piza (Listroscelinae) (Riek, 1976), Neduba macneilli Rentz \& Birchim, Neduba sierranus Rehn \& Hebard (Decticinae) (Morris et al., 1975). Most tettigoniids have structurally distinct left and right forewings and overlap them 'left above'. In the Neduba species some individuals show left above, some right above. Unlike Cyphoderris they appear to maintain their particular overlap as individuals through life. Both overlaps were represented by Riek's two (pinned) specimens of $M$. speculatum.

Spooner (1973) analysed the calling song of C. monstrosa and describes it as a trill of grylloid (sinusoidal) pulses at a carrier frequency of $13 \mathrm{kHz}$. He noted substantial variation in the intensity and frequency of pulses and suggested that these changes "reflect irregular switching of tegmina from top to bottom position". He refers to this habit as "switch-wing singing" and regards it as occurring several to many times in the course of a single trill.

Overlap at rest (i.e. between singing bouts) is very infrequently changed in C. buckelli. The overlap of 16 individually-caged males was monitored by examining them once a day during almost 2 weeks. Of 141 checks, only 4 reversals from the immediately previous overlap were observed; the incidence of resting overlap reversal was less than $3 \%$. Thirteen of these males never showed an overlap reversal.

Four C. monstrosa males checked over 5 days, gave similar results: two were never found with reversed overlap (checked respectively 5 and 6 times), one was reversed once in 5 checks and one twice in 6 checks. If Cyphoderris alter overlap several times within a single trill, it is strange that individuals end up so consistently at the same overlap with which they began. 
We recorded the calling song of a $C$. monstrosa specimen (Figure $6,75-6)$ before and after damaging with a scalpel, several teeth in the central region of his right tegmen file. In oscillograms of postmutilation recorded song, his use of the damaged file (i.e. right above overlap) was apparent as a drastic mid-pulse drop in amplitude. In one oscillogram, a portion of which makes up Figure 6 (second trace from bottom), 20 pulses in succession were 'right above'.

Switch-wing singing as suggested by distinctive pulse envelopes within the same trill was only evident in our records on one occasion. A male of $C$. monstrosa had been released in the immediate vicinity (i.e. within antennal range) of a mature fernale on the observer's hand. He began to sing while walking about on the hand and directing his attention toward the female. His song was recorded and on analysis found to be a trill in which every other pulse was identical in envelope and distinctly different from the intervening pulse i.e. there were two pulse types occurring in alternation without break in the sequence of the trill (Figure 6, bottom trace). This was apparently a courtship song.

It is clear that pulse envelopes are highly variable in the genus, though usually quite consistent for a particular recording session of a particular individual. Switch-wing stridulation is probably not an everyday feature of $C$. monstrosa calling song but it may occur under special circumstances such as courtship.

Oscillograms of normal calling songs are given in Figure 6. The pulses of $C$. strepitans and C. buckelli are apparently indistinguishable. They are usually wedge-shaped: each begins with a steep rise to maximum amplitude, then falls steadily to the pulse's end. The pulses of $C$. monstrosa also have a steep onset but are usually of longer duration. They are drawn out in an uneven envelope near their maximum amplitude before dropping away to silence.

Carrier frequency spectra of all three species are highly similar. Specimens were analysed 'live' (i.e. without tape-recording) by directing the output of a Bruel \& Kjaer sound level meter (2204) fitted with a $1 / 4$ " microphone (4135) into a Tektronix 3L5 spectrum analyser. This system will detect ultrasonic frequencies up to 100 $\mathrm{kHz}$. No substantial sound energy exists in the ultrasonic range for any of the Cyphoderris species. The sinusoidal nature of the waveform is apparent in the narrowness of the dominant frequency 


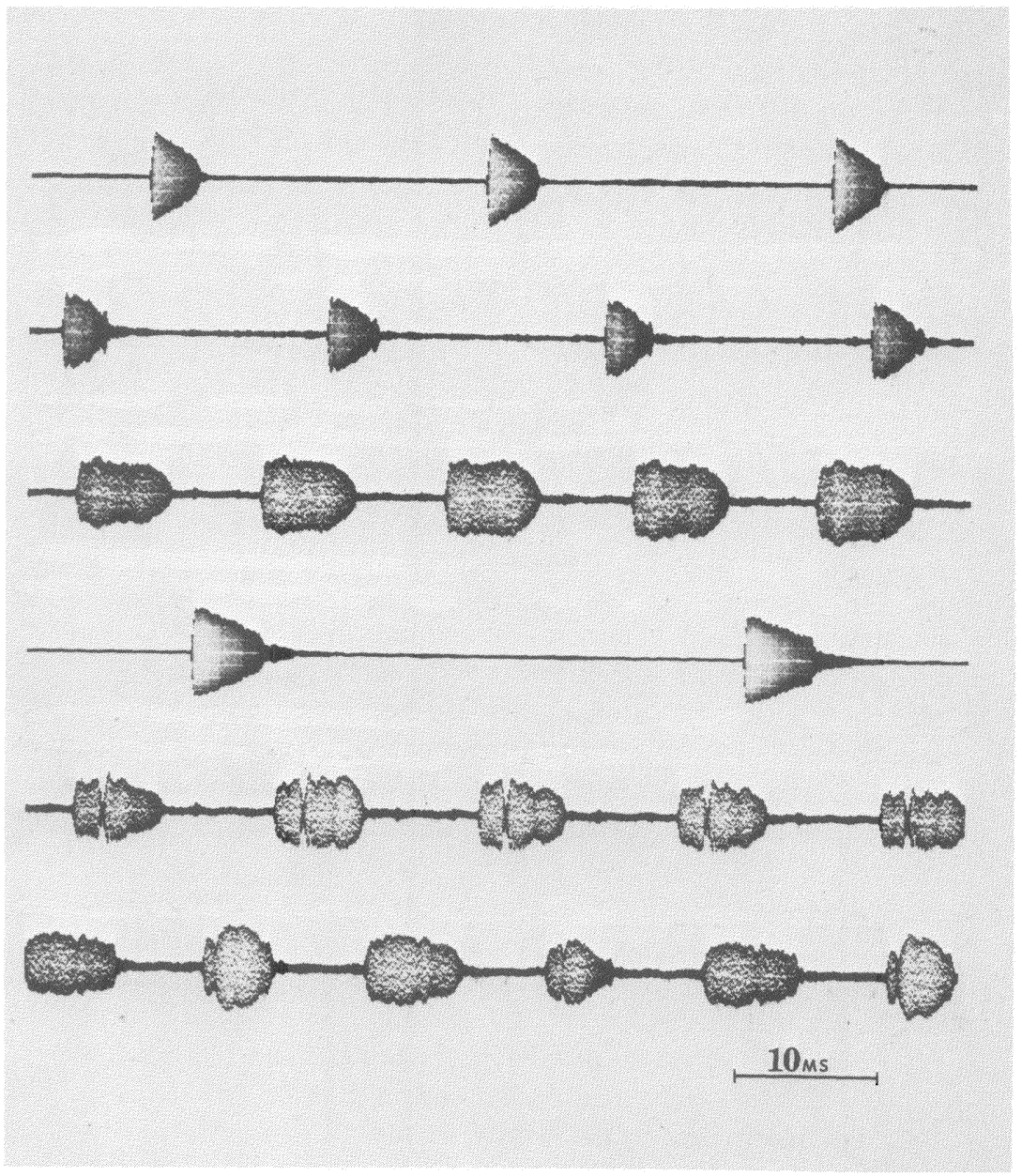

Figure 6. Oscillograms of Cyphoderris calling song. From top trace downward: C. strepitans $76-8,17.8^{\circ} \mathrm{C}$; C. buckelli $76-14,25.0^{\circ} \mathrm{C} ;$ C. monstrosa $75-6,24.5^{\circ} \mathrm{C}$, intact file; $C$. monstrosa $76-2,8.7^{\circ} \mathrm{C}$, field-recorded, Monck Prov. Pk B.C.; $C$. monstrosa $75-6,24.0^{\circ} \mathrm{C}$, file teeth of right forewing damaged; $C$. monstrosa $75-10$, $23.1^{\circ} \mathrm{C}$, male recorded singing in immediate presence of female. 
peak, suggesting the operation of a sharply-tuned (high Q) tegminal resonator (Sales \& Pye, 1974).

In the figured C. strepitans male (Figure 7), the dominant peak centers on $12.7 \mathrm{kHz}$ and there are very weak second and third harmonics near 25 and 38 respectively. The $C$. buckelli specimen has its principal peak near $13.3 \mathrm{kHz}$ and a lesser peak occupies the range $28-30 \mathrm{kHz}$. Like Spooner (1973) we obtained $13 \mathrm{kHz}$ as the dominant carrier frequency of $C$. monstrosa.

Sound level measurements were obtained with the $1 / 4$ " microphone and the 2204 meter, the latter on 'linear, fast' setting. At $5 \mathrm{~cm}$ dorsal aspect, the sound level of $C$. strepitans (76-7) was between 100.5 and $101.0 \mathrm{~dB}$. A specimen of $C$. buckelli (76-3) was $102 \pm 2 \mathrm{~dB}$ at $6.5 \mathrm{~cm}$ dorsal.

Pulse rate varies linearly with temperature (Figure 8 ) as in other acoustic Ensifera (Walker 1962, 1975). Both field and laboratory recordings of calling song contributed to the regression lines. One $C$. monstrosa plotted point is from Spooner (1973) (S in Figure 8); 5
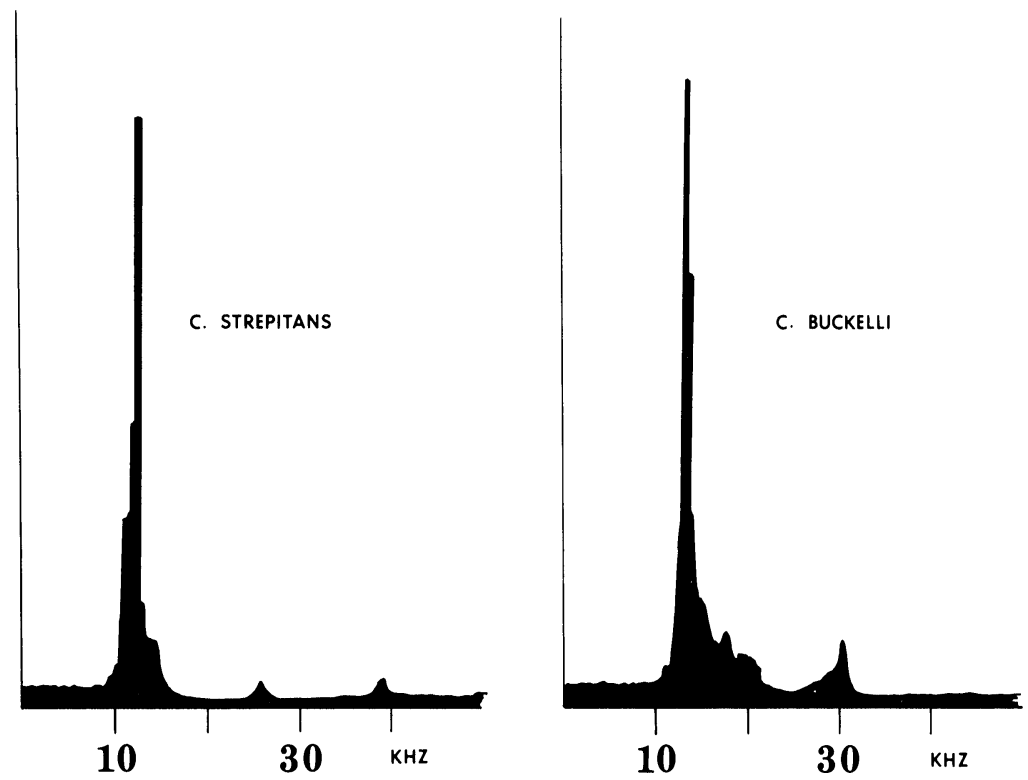

Figure 7. Calling song frequency spectrograms traced from photographs. 
different males provide the other 6 points. C. buckelli's regression is based on 12 different individuals, 3 at two different temperatures each. Each of the $13 \mathrm{C}$. strepitans pulse rates derives from a different individual; all those at temperatures of $8^{\circ} \mathrm{C}$ and below are field recordings. Pulse rates were calculated from an oscilloscope display in which a single bearn sweep embraced 3-13 pulses. Successive, single-sweep samples (3-6), were averaged to obtain each plotted value. The coefficients of determination indicate a very good fit to the calculated regression lines. Although the $C$. monstrosa regression line is different from the strepitans and buckelli lines the slopes and $\mathrm{Y}$ intercepts of the latter two species are not significantly different.

C. strepitans males stridulate at very low temperatures. Previous reports cite minimal singing temperatures for acoustic Orthoptera of about $7^{\circ} \mathrm{C}$ [e.g. Fulton (1925) for the tree cricket Oecanthus fultoni (under the name of $O$. niveus) and Frings and Frings (1957) for the katydid Neoconocephalus ensiger]. On May 17, 1977, at the holotypic site, one of us (D.T.G.) heard three of four males singing from branches and logs near the ground when the air temperature at waist level was $-0.5^{\circ} \mathrm{C}$. On June 4 and 5,1978 , tape recordings were made of males singing at temperatures as low as $2^{\circ} \mathrm{C}$ (see Figure 8 ). Following the recording the thermometer bulb was placed close to the singing male's perch. There is a suggestion in the plotted rates in Figure 8 of a departure from linearity at very low temperatures.

In conclusion, the song of $C$. monstrosa differs from the other two species in both the shape of the pulse amplitude envelope and in pulse rate, both these parameters being useful diagnostic features. C. buckelli and C. strepitans, however, have virtually identical calling songs: song intensities, carrier frequencies, and pulse amplitude envelopes provide no basis for human discrimination; the pulse rates, especially, are indistinguishable at any given temperature.

It is interesting to note that Alexander (1969) has questioned the traditional interpretation that reproductive isolating mechanisms evolved to prevent "mating mistakes" between species. He suggested (citing evidence from acoustical insects) that species differences have most likely arisen as a result of the different selection pressures operating on populations while they are in allopatry. He reasoned that if this is so, among other things, we should rarely find identical pair forming signals among allopatric or allochronic species. $C$. strepitans and $C$. buckelli are allopatric (Figure 5) and by the above 


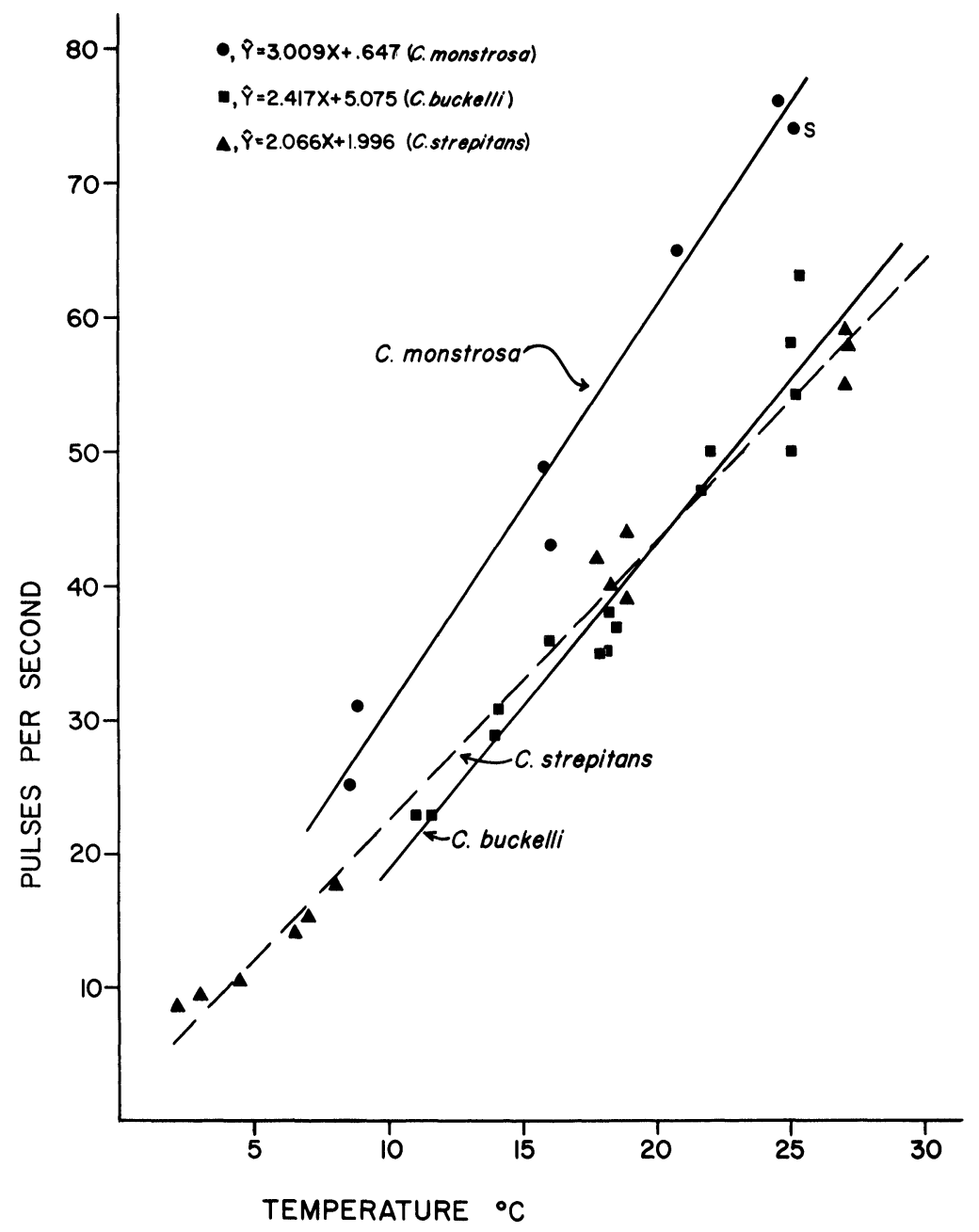

Figure 8. Relation of pulse rate and temperature in Cyphoderris calling song ( $\mathrm{S}$ is from Spooner, 1973). 
reasoning their songs should have diverged yet this is not the case. Any difference between these two species (including the above mentioned habitat differences) apparently have not affected their pair forming signals.

\section{ACKNOWLEDGEMENTS}

These studies were supported by operating grant 4946 from the National Research Council of Canada. Appreciation is extended to the many persons who provided us with access to specimens: $R$. D. Alexander (Univ. of Michigan), W. F. Barr (Univ. of Idaho), D. R. Davis \& A. B. Gurney (Smithsonian, Washington), K. Goeden (Oregon Dept. of Agriculture), J. D. Lattin \& D. C. Lightfoot (Oregon State Univ.), J. E. H. Martin (Biosystematics, Ottawa), D. Otte (Acad. Nat. Sciences Philadelphia), G. G. E. Scudder (Univ. of B.C.), Margaret Thayer (Harvard), W. J. Turner (Washington State Univ.), Bob Willey (Univ. of Chicago), S. M. Ulagaraj and V. R. Vickery (Macdonald College) and G. B. Wiggins (Royal Ontario Museum). We are grateful for the help of the staff of the Kananaskis Environmental Centre in Alberta (Univ. of Calgary). Jim Fullard, Darlene Morris and E. J. Morris helped with field studies. T. J. Walker (Univ. of Florida) and T. Alloway (Univ. of Toronto) transported specimens. Dr. Howard E. Evans criticized the manuscript. Beyond all others we acknowledge the help of Ron Aiken of the Univ. of Toronto.

\section{REFERENCES}

Alexander, R. D.

1969. Comparative animal behavior and systematics. Syst. Biol. Proc. Internat. Conf. Nat. Acad. Sciences, pp. 494-517.

Alexander, G.

1935. Orthoptera new to Colorado. Entomol. News 46: 30. ANDER, K.

1938. Ein abdominales Stridulationsorgan bei Cyphoderris (Prophalangopsidae) und über die systernatische Einteilung der Ensiferen (Saltatoria). Opuscula Entomol. 3: 32-38.

1939. Vergleichend-anatomische und phylogenetische Studien über die Ensifera (Saltatoria). Opuscula Entomol. Suppl. II, 306 pp. (Unpublished translation by T. H. Hubbell.) 
BuCKell, E. R.

1924. Additions and corrections to the list of British Columbia Orthoptera. Proc. Entomol. Soc. British Columbia 21: 7-12.

Caudell, A. N.

1904. The genus Cyphoderris. J.N.Y. Entomol. Soc. 12: 47-53.

Cowan, I. MCT. AND C. J. Guiguet.

1965. The Mammals of British Columbia. Handbook No. 11, British Columbia Provincial Museum, 3rd ed., 414 pp.

DUMORTIER, B.

1963. Morphology of sound emission apparatus in Arthropoda. In Busnel, R.-G., ed., Acoustic Behaviour of Animals. Elsevier, Amsterdam, pp. $277-345$.

Evans, H. E.

1970. Ecological-behavioral studies of the wasps of Jackson Hole, Wyoming. Bull. Mus. Comp. Zool. 140: 451-511.

Frings, H. AND M. FRINGS.

1957. The effects of temperature on chirp-rate of male cone-headed grasshoppers, Neoconocephalus ensiger. J. Exp. Zool. 134: 411-425.

FULTON, B. B.

1925. Physiological variation in the snowy-tree cricket, Oecanthus niveus DeGeer. Ann. Entomol. Soc. Amer. 18: 363-383.

1930. Notes on Oregon Orthoptera with descriptions of new species and races. Ann. Entomol. Soc. Amer. 23: 611-641.

Gleason, H. A. and A. Cronguist.

1964. The Natural Geography of Plants. Columbia Univ. Press, New York, $420 \mathrm{pp}$.

HeBard, M.

1934. Cyphoderris, a genus of katydid of southwestern Canada and the northwestern United States. Trans. Am. Entomol. Soc. 59: 371-375.

Kevan, D. K. MCE.

1954. Méthodes inhabituelles de production de son chez les Orthoptères. In Busnel, R.-G., ed., L'Acoustique des Orthoptères. Ann Épiphyt., Fasc. Special, pp. 103-141.

Morris, G. K., R. B. Aiken AND G. E. Kerr.

1975. Calling songs of Neduba macneilli and N. sierranus (Orthoptera: Tettigoniidae: Decticinae). J.N.Y. Entomol. Soc. 83: 229-234.

RAGGE, D. R.

1955. The Wing-venation of the Orthoptera Saltatoria with Notes On Dictyopteran Wing-venation. British Museum Natural History, London, $159 \mathrm{pp}$.

RIEK, E. F.

1976. The Australian genus Tympanophora White (Orthoptera: Tettigoniidae: Tympanophorinae). J. Aust. Entomol. Soc. 15: 161-171.

Sales, G. and D. Pye.

1974. Ultrasonic Communication by Animals. Chapman and Hall, London, $281 \mathrm{pp}$. 
Sharov, A. G.

1968. Phylogeny of the Orthopteroidea. Trans. Paleontol. Inst. Acad. Sci. U.S.S.R. 118: 1-216. (English ed., Israel Prog. Sci. Transl. 1971, pp. 1-251.)

SPOONER, J. D.

1973. Sound production in Cyphoderris monstrosa (Orthoptera: Prophalangopsidae). Ann. Entomol. Soc. Amer. 66: 4-5.

Thomas, C.

1876. A list of Orthoptera, collected by J. Duncan Putnam, of Davenport, Iowa, during the summers of 1872-3-4 \& 5, chiefly in Colorado, Utah and Wyoming Territories. Proc. Davenport Acad. Nat. Sci. 1: 249-264, pl. 36 .

UHLER, P. R.

1864. Orthopterological contributions, Gryllodea. Proc. Entomol. Soc. Phil. 2: $543-555$.

WALKER, T. J.

1962. Factors responsible for intraspecific variation in the calling songs of crickets. Evolution 16: 407-428.

1975. Effects of temperature on rates in poikilotherm nervous systems: evidence from the calling songs of meadow katydids (Orthoptera: Tettigoniidae: Orchelimum) and re-analysis of published data. J. Comp. Physiol. 101: 57-69.

WILley, R. B. AND R. L. WiLley.

1963. Range extension of Colorado Cyphoderris (Orthoptera: Prophalangopsidae). Entomol. News 74: 200-201.

ZEUNER, F. E.

1939. Fossil Orthoptera Ensifera. British Museum Natural History, London, $321 \mathrm{pp}$. 

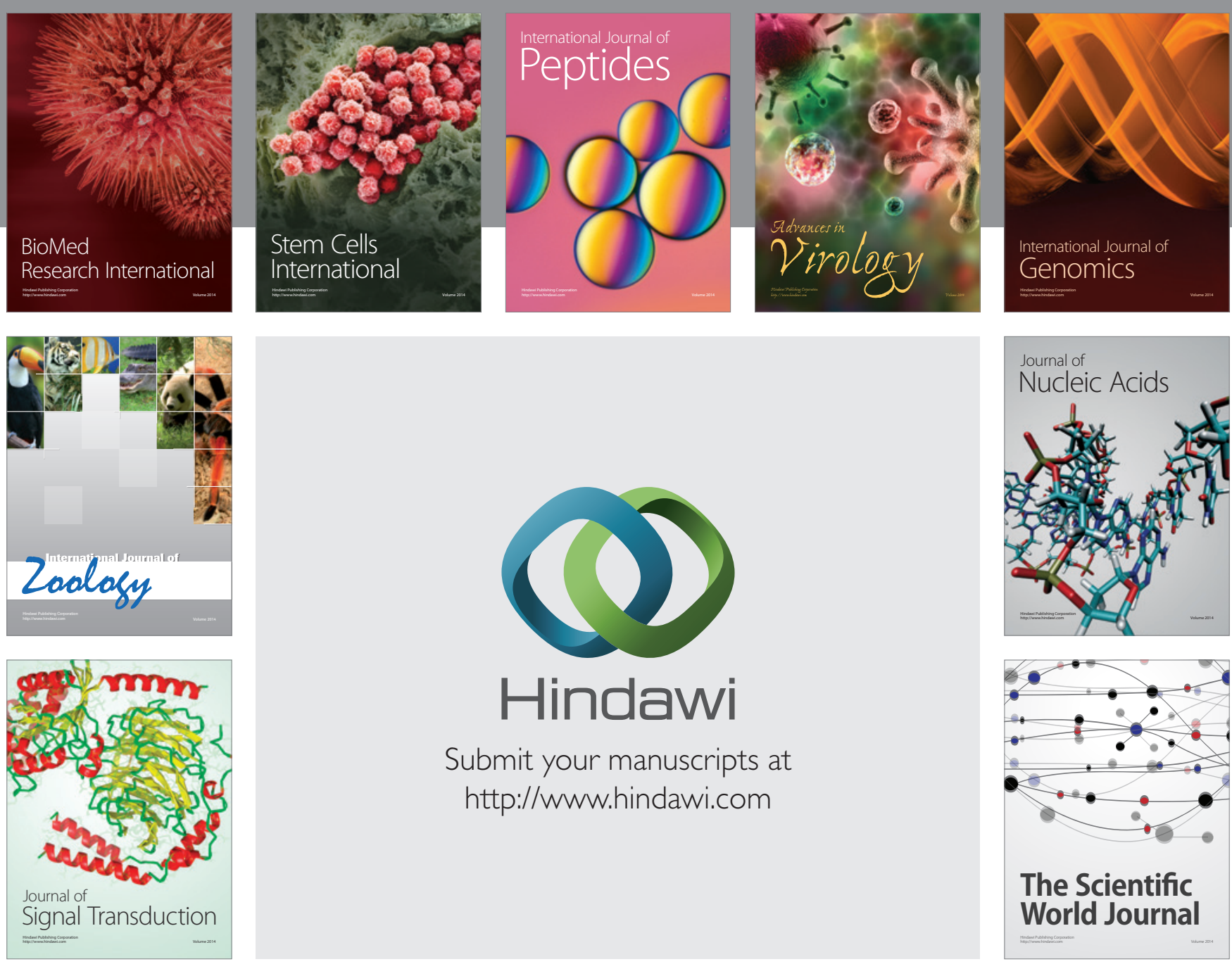

Submit your manuscripts at

http://www.hindawi.com
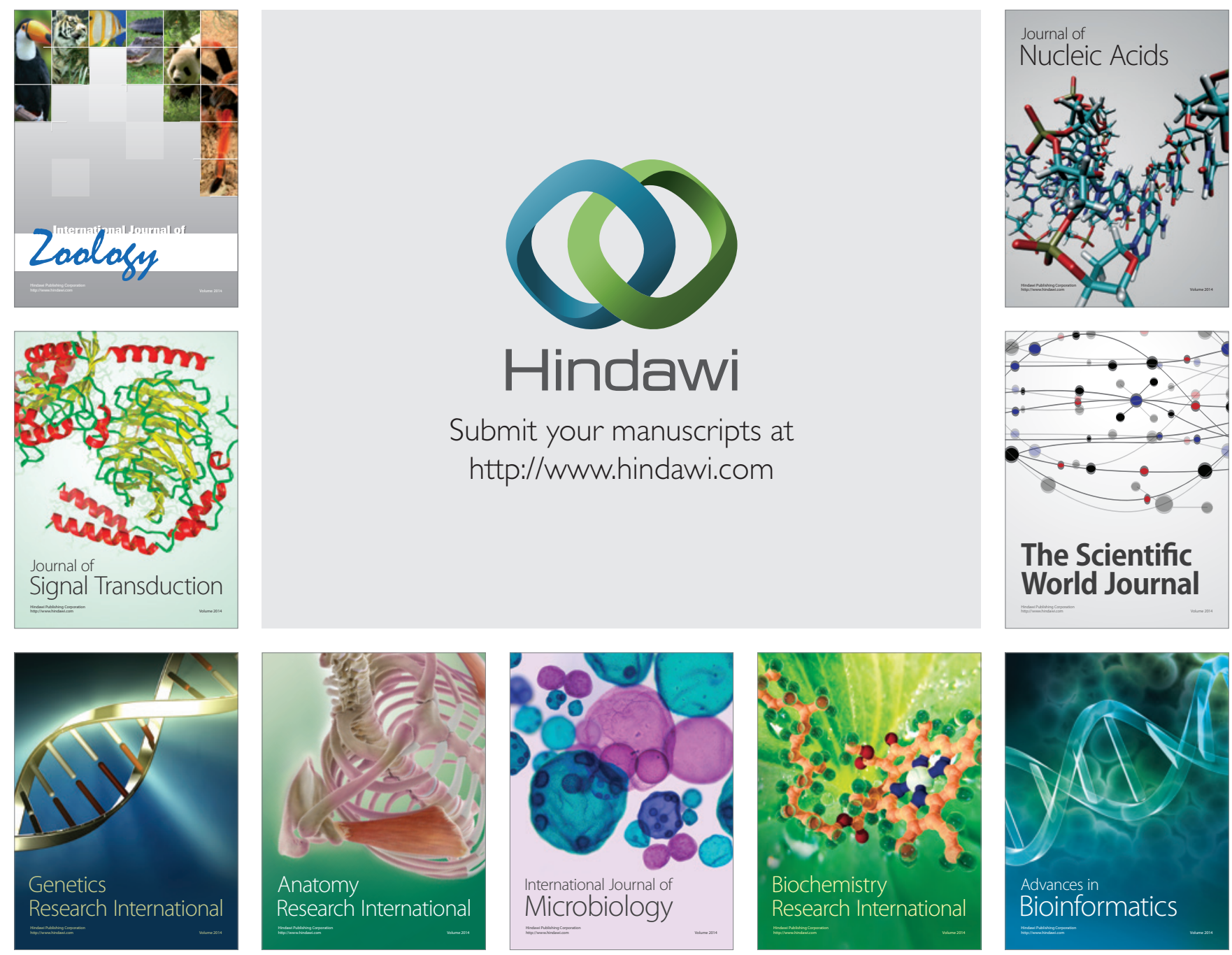

The Scientific World Journal
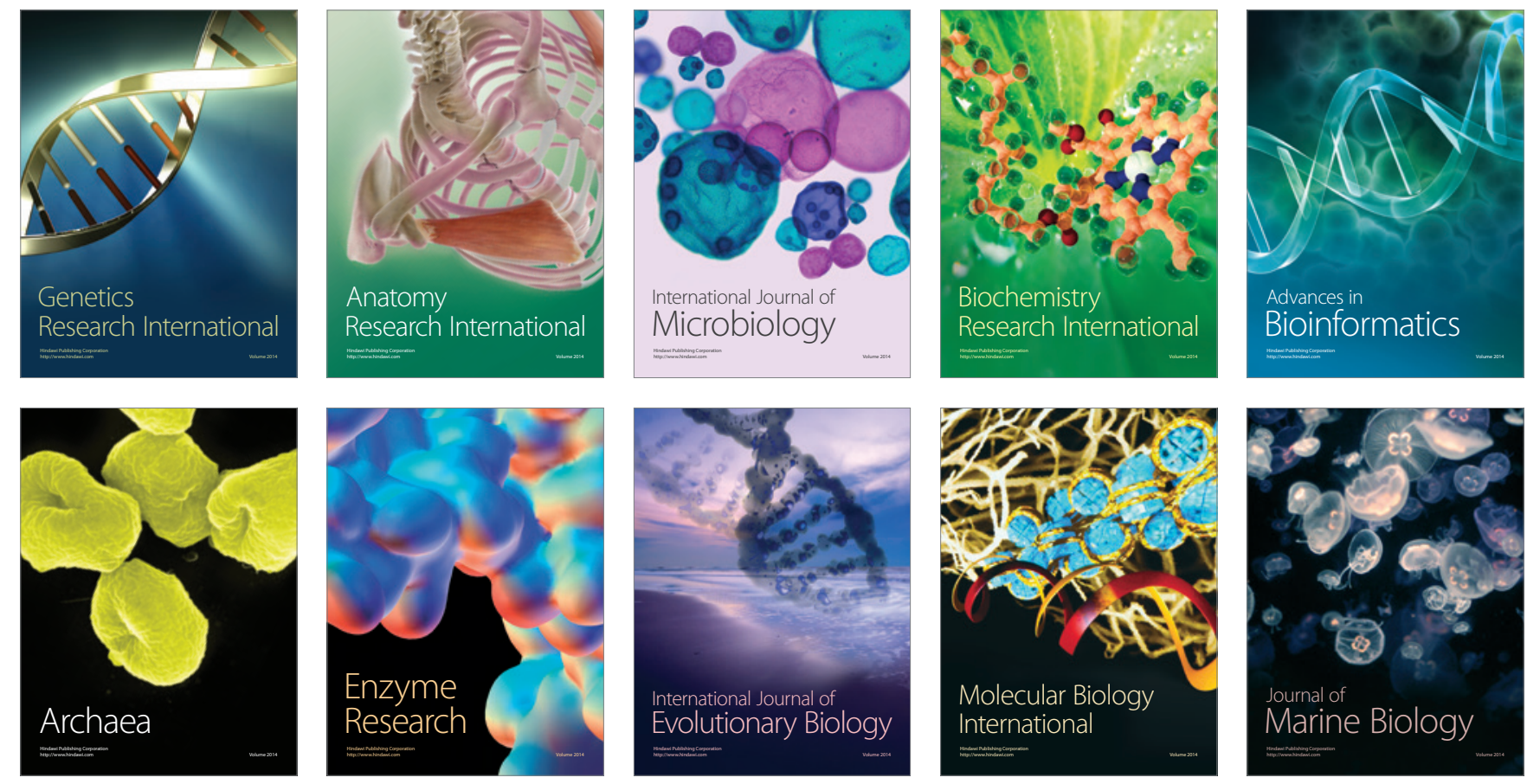